\title{
Prevalence of Metabolic Syndrome according to Menopausal Status: The 5th Korea National Health \& Nutrition Examination Survey
}

\author{
Kyung-A Shin \\ Department of Clinical Laboratory Science, Shinsung University, Dangjin 343-861, Korea
}

\begin{abstract}
The purpose of this study was to investigate the prevalence and differences of risk factors of Metabolic syndrome according to menopausal status. From the database of the 5th Korea National Health and Nutrition Examination Survey (KNHANES V) conducted in 2012, data of 3,537 women who responded to health interview and health examination questionnaires. The presence of Metabolic syndrome was assessed using the International Diabetes Federation (IDF) criteria. The prevalence of Metabolic syndrome was $17.3 \%$ in premenopause and $54.3 \%$ in postmenopause. BMI, waist circumference, blood pressure, total cholesterol, LDL cholesterol, triglyceride, and Ferritin were higher in postmenopausal women compared to premenopausal women. However, postmenopausal women had lower HDL cholesterol and TIBC when compared to premenopausal women. Hypertension was the most prominent characteristic of postmenopausal women. Low HDL cholesterol showed up as a meaningful factor in premenopausal women. According to multiple regression analysis, waist circumference, fasting glucose, and HDL cholesterol were independent predictors of menopause. Therefore, obesity control and blood lipids management is recommended for postmenopausal women.
\end{abstract}

Keywords: Metabolic syndrome, Korea National Health and Nutrition Examination Survey, Postmenopause

This is an Open Access article distributed under the terms of the Creative Commons Attribution Non-Commercial License (http://creativecommons.org/licenses/by-nc/3.0) which permits unrestricted non-commercial use, distribution, and reproduction in any medium, provided the original work is properly cited.

Copyright () 2014 The Korean Society for Clinical Laboratory Science. All rights reserved.
Corresponding author: Kyung-A Shin Department of Clinical Laboratory Science, Shinsung University, Dangjin 343-861, Korea Tel: 82-41-350-1408

E-mail: mobitz2@daum.net

Received: June 22, 2014

Revised: September 12, 2014

Accepted: September 17, 2014

\section{서 론}

대사증후군은 복부비만, 고지혈증, 고혈압, 공복혈당장애를 포 함한 대사이상을 동반하는 질환군으로써 대사증후군의 발생은 심 혈관 질환 및 뇌졸중, 제 2형 당뇨병 발생 위험을 증가시킨다 (NCEP, 2001; Levesque and Lamarche, 2008).

대사증후군 유병률은 성별에 따라 차이를 보이고 있으며, 남성 의 대사증후군 유병률은 40세 이상 나이가 들수록 감소하는 반면 여성은 나이가 들수록 증가하는 경향을 보인다(Kim 등, 2004; Lee 등, 2005).

특히 여성의 대사증후군 발생빈도는 미국의 경우 전체 여성의 $22.6 \%$, 폐경 여성의 경우 40 50\% 정도로 추정되며(Ford 등, 2002; Park 등, 2003), 우리나라 여성의 경우 국민건강영양조사 (Korea National Health \& Nutrition Examination Survey, $\mathrm{KNHANES}$ ) 결과에 따르면 50세 이상 여성에서 $50 \%$ 내외의 대사
증후군 유병률을 보이고 있다(Kim 등, 2004).

이러한 결과는 여성의 폐경이후 난소부전으로 인한 에스트로겐 감소로 체지방 분포의 변화에 따른 내장비만 및 복부비만을 유발하 며, 체지방의 재 분포에 의한 복부지방의 축적은 대사증후군과 밀 접한 관련성을 나타낸다(Carr, 2003; Lovejoy, 2003). 또한 폐경으 로 인해 혈중 지질대사 변화는 동맥경화, 혈당 및 인슐린 증가와 같 은 대사적, 내분비적 변화를 동반하며(Lee 등, 2005), 이와 함께 심 혈관 질환과 대사증후군 발생빈도는 폐경 이전보다 현저한 증가를 보인다(Kim 등, 2007; Moon 등, 2003).

실제적으로 폐경과 함께 고밀도 콜레스테롤(high density lipoprotein)은 감소하며 중성지방(triglyceride), 총콜레스테롤, 저밀도 콜레스테롤(low density lipoprotein)은 증가하는 것으로 알려져 있다(Carr, 2003; Kim 등, 2007).

이와 같이 폐경은 여성들에게 다양한 신체적 변화를 야기하며 만성 질환의 발병 가능성을 증가시키는 원인이 되고 있어, 폐경 여 
성의 건강관리에 있어 그 중요성이 강조되고 있다(Lee 등, 2012).

게다가 대사증후군 유병률과 함께 대사증후군 위험 요인에 있어 서도 폐경 유무에 따른 차이가 있을 것으로 유추되지만, 현재까지 이와 관련한 연구는 부족한 실정이다.

이에 본 연구에서는 최근 제 5 기 국민건강영양조사 자료를 토대 로 대사증후군에 대한 가장 최근의 진단기준인 세계당뇨협회 (International Diabetes Federation, IDF) 기준을 적용하여 폐경 유무에 따른 대사증후군 유병률과 대사증후군 위험 요인의 차이를 비교해보고자 하였다.

\section{재료 및 방법}

\section{1. 연구대상}

본 연구는 질병관리본부에서 실시한 제 5 기 국민건강영양조사 3차년도(2012) 원시자료를 이용하여 진행되었다. 전체 대상자 8,057 명의 조사자료에서 건강 설문조사 및 검진조사에 모두 참여 한 여성 3,537 명을 본 연구에서 분석하였다. 또한 국민건강영양조 사자료는 질병관리본부 연구윤리심의위원회의 심의 및 승인을 받 았다(승인번호; 2012-01EXP-01-2C).

\section{2. 자료수집 방법}

체중, 신장, 체질량지수(body mass index, BMI), 허리둘레를 포 함한 신체적 특성 및 혈액학적 지표, 폐경 및 흡연 여부에 대한 정보 는 국민건강영양조사의 건강 설문조사와 검진조사를 통해 수집되 었으며, 조사방법은 국민건강영양조사 보고서에 기술되어 있다 (KNHANES, 2012).

체질량지수는 체중 $(\mathrm{kg}) /$ 키 $\left(\mathrm{m}^{2}\right)$ 의 공식으로 구했으며, 허리둘레 는 늑골 하단부와 장골 능선 상단 두 지점을 촉지하여 중간 지점을 기준으로 측정하였다.

폐경여부는 여성건강 설문조사 내용 중 무월경 사유에서 자연 및 인공폐경을 선택한 대상자를 모두 폐경 대상자에 포함시켰다. 또한 흡연여부는 ‘흡연', '가끔흡연’, '과거엔 피웠으나, 현재 피우 지 않음' 모두를 흡연자로 간주하였다.

\section{3. 혈압 및 혈액측정 방법}

혈압은 앉은 자세에서 15 분간 안정을 취한 후 5 분 간격으로 3 회 측정하였으며, 두 번째와 세 번째 측정된 값의 평균값을 자료로 이 용하였다.

혈액검사는 8시간 이상 공복상태에서 혈액을 채취하여 분석한 결과이며, 제 5기 국민건강영양조사 2012년도에 실시된 혈액검사 자료에서 공복혈당(fasting glucose), 중성지방, 총콜레스테롤, 고
밀도 콜레스테롤, 저밀도 콜레스테롤, 당화혈색소( $\mathrm{HbA1c})$, 페리 틴(ferritin), 철(Fe), 철결합능(total iron binding capacity, TIBC) 을 혈액지표에 포함하였다.

\section{4. 대사증후군 진단기준}

세계 당뇨병협회에서 제시한 대사증후군의 진단기준에 따라 복 부비만 지표인 허리둘레가 $80 \mathrm{~cm}$ 이상이면서 다음 4 가지 중 2 가지 이상 해당할 경우 대사증후군으로 정의하였다. 1) 중성지방이 150 $\mathrm{mg} / \mathrm{dL}$ 이상이거나, 고지혈증 치료를 받는 경우 2) 고밀도 콜레스 테롤이 $50 \mathrm{mg} / \mathrm{dL}$ 미만인 경우 3) 수축기 혈압 $130 \mathrm{mmHg}$ 이상 혹 은 이완기 혈압 $85 \mathrm{mmHg}$ 이상으로 상승되어 있거나, 고혈압 치료 를 받고 있는 경우 4) 공복혈당이 $100 \mathrm{mg} / \mathrm{dL}$ 이상이거나 제 2 형 당 뇨병으로 약물 치료 중인 경우로 하였다(IDF, 2006).

\section{5. 통계방법}

본 연구의 통계 분석은 SPSS 19.0 을 이용하였으며, 모든 자료는 평균 \pm 표준편차로 나타냈다. 또한 복합표본설계를 고려한 가중치 를 반영하여 분석하였다.

폐경전후의 대사증후군 유병률의 차이 및 범주형 변수의 집단간 비교는 chi-squared test를 실시하였다. 또한 폐경전후에 대상자 의 의학적 특징 및 대사증후군 관련 요인의 차이를 비교하기 위해 독립표본 $t$ 검정(independent $t$-test)을 실시하였다.

폐경유무가 영향을 미치는 대사증후군 위험요인을 알아보기 위 해 복합표본 다변량선형회귀분석(complex samples multivariable linear regression)을 실시하였으며, 통계적 유의수준은 $p<0.05$ 로 설정하였다.

\section{결 과}

\section{1. 폐경전후 대상자의 의학적 특징}

폐경전후 대상자의 의학적 특징은 Table 1 과 같다. 체질량지수, 허리둘레는 폐경전 여성보다 폐경후 여성이 유의하게 높았으며(각 각 $p<0.001$, 수축기와 이완기 혈압도 폐경후 여성에서 유의하게 높았다(각각 $p<0.001$ ). 총콜레스테롤, 저밀도 콜레스테롤, 중성 지방, 공복혈당, 당화혈색소, 페리틴은 폐경전 여성보다 폐경후 여 성이 유의하게 높았으며(각각 $p<0.001$, 고밀도 콜레스테롤과 철 결합능은 폐경전 여성보다 폐경후 여성이 유의하게 낮은 것으로 나 타났다(각각 $p<0.001)$. 그러나 체중과 혈청 철, 미세알부민은 폐 경 전후에 차이가 없었다. 또한 흡연은 폐경전 여성이 폐경후 여성 보다 유의하게 높은 빈도를 보였다 $(p<0.001)$. 
Table 1. Clinical characteristics of the subjects

\begin{tabular}{|c|c|c|c|}
\hline Variables & Postmenopause $(n=1714)$ & Premenopause $(\mathrm{n}=1823)$ & $p$ value \\
\hline Age (years) & $64.54 \pm 9.43$ & $33.34 \pm 11.25$ & $<0.001^{\star \star}$ \\
\hline Height (cm) & $153.18 \pm 6.10$ & $160.12 \pm 5.39$ & $<0.001^{\star *}$ \\
\hline Weight (kg) & $57.15 \pm 9.01$ & $57.35 \pm 9.70$ & 0.512 \\
\hline BMI $\left(\mathrm{kg} / \mathrm{m}^{2}\right)$ & $24.32 \pm 3.34$ & $22.36 \pm 3.60$ & $<0.001^{\star *}$ \\
\hline$W C(\mathrm{~cm})$ & $82.04 \pm 9.06$ & $74.34 \pm 9.04$ & $<0.001^{\star \star}$ \\
\hline Systolic BP (mmHg) & $126.85 \pm 17.70$ & $108.28 \pm 12.24$ & $<0.001^{\star \star}$ \\
\hline Diastolic BP (mmHg) & $75.65 \pm 9.61$ & $71.36 \pm 9.52$ & $<0.001^{* *}$ \\
\hline Total cholesterol (mg/dL) & $200.43 \pm 37.46$ & $179.51 \pm 32.93$ & $<0.001^{\star \star}$ \\
\hline $\mathrm{HDL}$-cholesterol (mg/dL) & $51.73 \pm 12.22$ & $56.86 \pm 12.54$ & $<0.001^{\star *}$ \\
\hline LDL-cholesterol (mg/dL) & $121.75 \pm 34.00$ & $103.67 \pm 28.08$ & $<0.001^{\star *}$ \\
\hline Triglyceride $(\mathrm{mg} / \mathrm{dL})$ & $134.98 \pm 78.93$ & $95.23 \pm 82.26$ & $<0.001^{\star *}$ \\
\hline Glucose (mg/dL) & $101.75 \pm 22.68$ & $91.39 \pm 16.45$ & $<0.001^{\star \star}$ \\
\hline $\mathrm{HbA1c}(\%)$ & $6.11 \pm 0.90$ & $5.51 \pm 0.68$ & $<0.001^{\star \star}$ \\
\hline Ferritin (ng/mL) & $69.90 \pm 63.28$ & $30.63 \pm 32.11$ & $<0.001^{\star *}$ \\
\hline $\mathrm{Fe}(\mu \mathrm{g} / \mathrm{dL})$ & $102.77 \pm 34.28$ & $102.46 \pm 48.56$ & 0.833 \\
\hline $\operatorname{TIBC}(\mu \mathrm{g} / \mathrm{dL})$ & $314.24 \pm 41.77$ & $333.98 \pm 51.38$ & $<0.001^{\star \star}$ \\
\hline microalbumin $(\mu \mathrm{g} / \mathrm{mL})$ & $23.88 \pm 91.33$ & $19.04 \pm 116.57$ & 0.202 \\
\hline
\end{tabular}

Values are presented as Mean $\pm \mathrm{SD}$. ${ }^{\star *} p<0.001$. Abbreviation: BMI, body mass index; WC, waist circumference; BP, blood pressure; HDL, high density lipoprotein; LDL, low density lipoprotein; HbA1c, hemoglobin A1c; TIBC, total iron binding capacity.

Table 2. Differences of risk factors with and without metabolic syndrome in postmenopausal women

\begin{tabular}{|c|c|c|c|c|c|c|}
\hline \multirow{2}{*}{ Variables } & \multicolumn{2}{|c|}{ Postmenopause $(n=1714)$} & \multirow{2}{*}{$p$ value } & \multicolumn{2}{|c|}{ Premenopause (n=1823) } & \multirow{2}{*}{$p$ value } \\
\hline & MetS $(n=930)$ & Non-MetS (n=784) & & MetS $(n=315)$ & Non-MetS $(n=1508)$ & \\
\hline Age (years) & $65.88 \pm 9.00$ & $62.89 \pm 9.68$ & $<0.001^{\star \star}$ & $39.59 \pm 8.51$ & $32.03 \pm 11.31$ & $<0.001^{\star *}$ \\
\hline Height $(\mathrm{cm})$ & $153.41 \pm 5.76$ & $152.90 \pm 6.49$ & 0.084 & $159.63 \pm 5.48$ & $160.21 \pm 5.37$ & 0.088 \\
\hline Weight (kg) & $61.36 \pm 8.30$ & $52.09 \pm 6.98$ & $<0.001^{\star \star}$ & $68.73 \pm 9.51$ & $54.96 \pm 7.88$ & $<0.001^{\star \star}$ \\
\hline BMI $\left(\mathrm{kg} / \mathrm{m}^{2}\right)$ & $26.04 \pm 3.05$ & $22.26 \pm 2.36$ & $<0.001^{\star \star}$ & $26.93 \pm 3.28$ & $21.40 \pm 2.86$ & $<0.001^{\star \star}$ \\
\hline WC $(\mathrm{cm})$ & $87.85 \pm 6.48$ & $75.02 \pm 6.37$ & $<0.001^{\star \star}$ & $87.56 \pm 7.08$ & $71.55 \pm 7.21$ & $<0.001^{\star \star}$ \\
\hline Systolic BP (mmHg) & $130.47 \pm 16.51$ & $122.74 \pm 18.09$ & $<0.001^{\star \star}$ & $116.58 \pm 15.83$ & $106.51 \pm 10.56$ & $<0.001^{\star \star}$ \\
\hline Diastolic BP (mmHg) & $76.58 \pm 9.98$ & $74.63 \pm 9.00$ & $<0.001^{\star \star}$ & $77.02 \pm 11.73$ & $70.18 \pm 8.53$ & $<0.001^{\star \star}$ \\
\hline Total cholesterol (mg/dL) & $200.37 \pm 38.76$ & $200.52 \pm 35.86$ & 0.941 & $193.93 \pm 38.11$ & $176.35 \pm 30.85$ & $<0.001^{\star \star}$ \\
\hline HDL-cholesterol (mg/dL) & $49.09 \pm 11.50$ & $54.92 \pm 12.31$ & $<0.001^{\star \star}$ & $48.90 \pm 10.96$ & $58.61 \pm 12.21$ & $<0.001^{\star \star}$ \\
\hline LDL-cholesterol (mg/dL) & $121.02 \pm 35.38$ & $122.64 \pm 32.27$ & 0.346 & $113.22 \pm 34.28$ & $101.55 \pm 26.11$ & $<0.001^{\star \star}$ \\
\hline Triglyceride (mg/dL) & $151.88 \pm 88.28$ & $114.45 \pm 59.79$ & $<0.001^{\star \star}$ & $159.36 \pm 153.69$ & $81.36 \pm 45.28$ & $<0.001^{\star *}$ \\
\hline Glucose (mg/dL) & $106.26 \pm 24.78$ & $96.26 \pm 18.39$ & $<0.001^{\star \star}$ & $102.46 \pm 31.47$ & $88.98 \pm 9.12$ & $<0.001^{\star \star}$ \\
\hline $\mathrm{HbA} 1 \mathrm{c}(\%)$ & $6.26 \pm 0.97$ & $5.92 \pm 0.76$ & $<0.001^{\star \star}$ & $5.91 \pm 1.05$ & $5.42 \pm 0.53$ & $<0.001^{\star \star}$ \\
\hline Ferritin (ng/mL) & $73.49 \pm 63.99$ & $65.57 \pm 62.19$ & $0.013^{\star}$ & $37.23 \pm 42.04$ & $29.20 \pm 29.33$ & $0.002^{\star}$ \\
\hline $\mathrm{Fe}(\mu \mathrm{g} / \mathrm{dL})$ & $100.57 \pm 32.65$ & $105.81 \pm 35.97$ & $0.002^{*}$ & $100.10 \pm 47.17$ & $103.07 \pm 48.88$ & 0.332 \\
\hline $\mathrm{TIBC}(\mu \mathrm{g} / \mathrm{dL})$ & $316.93 \pm 42.86$ & $310.91 \pm 40.21$ & $0.004^{\star}$ & $348.64 \pm 58.10$ & $330.63 \pm 49.12$ & $<0.001^{\star \star}$ \\
\hline microalbumin $(\mu \mathrm{g} / \mathrm{mL})$ & $30.94 \pm 114.39$ & $15.51 \pm 50.52$ & $<0.001^{\star \star}$ & $36.73 \pm 241.59$ & $15.11 \pm 59.74$ & 0.146 \\
\hline Smoking, n (\%) & $54(5.8)$ & $58(7.4)$ & 0.196 & $45(14.3)$ & $176(11.7)$ & $<0.001^{\star \star}$ \\
\hline
\end{tabular}

Values are presented as Mean $\pm \mathrm{SD} .{ }^{*} p<0.05$, ${ }^{* *} p<0.001$. Abbreviation: MetS, metabolic syndrome; BMI, body mass index; WC, waist circumference; BP, blood pressure; HDL, high density lipoprotein; LDL, low density lipoprotein; HbA1C, hemoglobin A1c; TIBC, total iron binding capacity.

\section{2. 폐경여성의 대사증후군 유무에 따른 위험요인의 차이}

폐경후 여성의 대사증후군 유무에 따른 위험요인의 차이는 Table 2와 같다. 폐경여성에서 대사증후군 진단군의 연령이 대사 증후군 위험요인이 없는 군보다 높았다 $(p<0.001)$. 체중, 체질량 지수, 허리둘레는 대사증후군 진단군이 대사증후군 위험요인이 없
는 군보다 높았으며 $(p<0.001)$, 수축기와 이완기 혈압 또한 대사증 후군 진단군에서 유의하게 높았다 $(p<0.001)$. 중성지방, 공복혈 당, 당화혈색소는 대사증후군 위험요인이 없는 군보다 대사증후군 진단군이 유의하게 높았으며, 고밀도 콜레스테롤은 대사증후군 진 단군이 유의하게 낮았다 $(p<0.001)$. 페리틴과 철결합능은 대사증 후군 위험요인이 없는 군보다 대사증후군 진단군이 유의하게 높았 
88 Kyung-A Shin. Prevalence of Metabolic Syndroem according to Menopausal Status

Table 3. Prevalence of metabolic syndrome risk factors according to menopausal status

\begin{tabular}{lccc}
\hline \multicolumn{1}{c}{ Metabolic syndrome risk factors } & Postmenopause $(\mathrm{n}=1714)$ & Premenopause $(\mathrm{n}=1823)$ & $p$ value \\
\hline WC $(\geq 80 \mathrm{~cm})$ & $1038(60.6)$ & $461(25.3)$ & $<0.001^{* *}$ \\
Hypertriglyceridemia & $517(30.2)$ & $208(11.4)$ & $<0.001^{* *}$ \\
Low HDL-cholesterol & $737(43.0)$ & $512(28.1)$ & $<0.001^{* *}$ \\
High blood pressure or antihypertensive medication & $1058(61.7)$ & $212(11.6)$ & $<0.001^{\star *}$ \\
High fasting glucose or diabetes medication & $679(39.6)$ & $190(10.4)$ & $<0.001^{* *}$ \\
Total prevalence of metabolic syndrome & $930(54.3)$ & $315(17.3)$ & $<0.001^{* *}$ \\
\hline
\end{tabular}

Values are presented as number (\%).* $p<0.001$. Abbreviation: WC, waist circumference; HDL, high density lipoprotein.

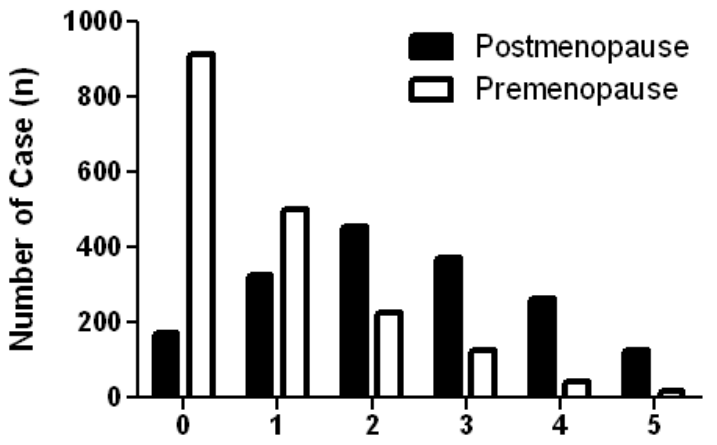

Number of risk factors for metabolic syndrome

Fig. 1. Difference between number of components of metabolic syndrome and menopause.

으며 $(p=0.013, p=0.004)$, 철은 대사증후군 진단군이 유의하게 낮 았다 $(p<0.002)$. 그러나 저밀도 콜레스테롤, 흡연빈도는 집단간 차이가 없었다. 또한 미세알부민은 대사증후군 진단군이 대사증후 군 위험요인이 없는 군보다 유의하게 높았다 $(p<0.001)$.

\section{3. 폐경전후의 대사증후군 위험요인 유병률}

폐경후 여성의 대사증후군 각 위험요인별 유병률은 고혈압 (61.7\%), 복부비만(60.6\%), 낮은 고밀도 콜레스테롤(43.0\%), 고혈 당(39.6\%), 고중성지방혈증(30.2\%) 순으로 높은 유병률을 보였으 며, 대사증후군 위험요인 모두 폐경전 보다 폐경후 여성에서 유의 하게 높은 빈도를 보였다(각각 $p<0.001)$. 폐경전 여성의 경우 낮 은 고밀도 콜레스테롤이 높은 빈도로 나타났다. 또한 복부비만이 있으면서 네가지 위험요인 중 2가지 이상에 해당되는 대사증후군 유병률은 폐경후 여성은 $54.3 \%$ 였으며, 폐경전 여성은 $17.3 \%$ 로 폐 경후 여성에서 유의하게 높은 빈도를 보였다 $(p<0.001)$ (Table 3$)$.

전체적으로 대사증후군 위험요인의 갯수가 폐경후 여성은 2개 의 위험요인을 갖고 있는 빈도가 가장 높은 반면, 폐경전 여성은 위 험요인이 없는 경우에서 높은 빈도를 보였다(Fig. 1).

\section{4. 폐경에 영향을 미치는 대사증후군 위험요인}

폐경에 영향을 미치는 대사증후군 위험요인을 알아보기 위해 연
Table 4. Complex samples multivariable linear regression with menopause and metabolic syndrome risk factors

\begin{tabular}{lrcc}
\hline Metabolic syndrome risk factors & \multicolumn{1}{c}{$\beta$} & \multicolumn{1}{c}{ SE } & \multicolumn{1}{c}{$p$ value } \\
\hline WC $(\mathrm{cm})$ & -0.251 & 0.001 & $0.001^{\star}$ \\
Glucose $(\mathrm{mg} / \mathrm{dL})$ & -0.118 & 0.000 & $<0.001^{\star *}$ \\
HDL-cholesterol $(\mathrm{mg} / \mathrm{dL})$ & 0.138 & 0.002 & $0.024^{\star}$ \\
LDL-cholesterol $(\mathrm{mg} / \mathrm{dL})$ & -0.053 & 0.002 & 0.723 \\
Triglyceride $(\mathrm{mg} / \mathrm{dL})$ & -0.005 & 0.000 & 0.951 \\
Total cholesterol & -0.183 & 0.002 & 0.283 \\
\hline
\end{tabular}

$R^{2}=0.223,{ }^{*} p<0.05,{ }^{*} p<0.001$. Abbreviation: $\mathrm{SE}$, standard error; WC, waist circumference; HDL, high density lipoprotein; LDL, low density lipoprotein.

령을 보정한 후 다변량선형회귀분석을 적용한 결과는 Table 4와 같 다. 폐경에 유의하게 영향을 미치는 대사증후군 위험요인은 허리둘 레 $(p=0.001)$, 공복혈당 $(p<0.001)$, 고밀도 콜레스테롤 $(p=0.024)$ 로 나타났다.

\section{고 찰}

본 연구결과 폐경후 여성에서 체질량지수, 허리둘레, 혈압, 공복 혈당, 총콜레스테롤, 저밀도 콜레스테롤 및 중성지방, 페리틴이 높 게 나타났으며, 고밀도 콜레스테롤, 철결합능은 낮게 나타났다. 또 한 대사증후군 유병률은 폐경전 여성은 $17.3 \%$ 인데 반해 폐경후 여 성의 경우 $54.3 \%$ 로 나타나, 폐경후 여성에서 특히 대사증후군에 대 한 관리가 필요한 것으로 나타났다.

폐경기 이후 여성은 에스트로겐 분비의 감소로 체지방 분포의 변화가 나타나며, 내장 및 복부비만의 증가로 대사증후군 발생 위 험이 증가한다(Lovejoy, 2003; Lee 등, 2005). 또한 고밀도 콜레스 테롤의 저하, 저밀도 콜레스테롤 및 중성지방의 증가와 같은 지질 대사의 이상은 동맥경화 위험도를 높이며, 혈당 증가와 인슐린 저 항성을 유발한다(Carr, 2003; Moon 등, 2003; Kim 등, 2007). 이 로 인하여 폐경 이전보다 폐경 이후에 심혈관 질환을 포함한 퇴행 성 질환의 발생빈도는 현저히 증가한다(NCEP, 2001).

대사증후군 유병률은 남녀간에 차이를 보이며, 남성의 경우 55 
세 이후감소하는 경향을 보인다(Kim 등, 2004). 반면 여성은 나이 가 들수록 대사증후군 유병률이 증가하는 경향을 보이는데, 55 세 이후부터는 남성의 유병률을 추월하여 급격한 증가를 보인다(Kim 등, 2004).

전체 여성의 대사증후군 유병률은 진단기준에 따라 차이는 있으 나 20\% 내외인 것으로 알려져 있다(Najarian 등, 2006; von Muhlen 등, 2007). 특히 50세 이상 여성을 대상으로 1998년 국민 건강영양조사자료의 결과에 따르면 $50 \%$ 의 유병률을 보고하였으 며(Kim 등, 2004), 제 5기 국민건강영양조사 2012년도 자료를 기 초한 본 연구결과는 $54.3 \%$ 의 유병률을 보이고 있어 폐경후 여성의 대사증후군은 지속적인 증가추세를 보이고 있다.

이와 같은 결과는 여성에 있어서 폐경후 대사증후군의 급격한 증가가 폐경에 따른 신체적·생리적 변화 자체이외에 연령 증가에 따른 영향으로 보는 연구결과도 있어 노령인구 증가에 따른 결과로 유추해볼 수 있다(Figueiredo 등, 2010; Pandey 등, 2010; Lee 등, 2012).

대사증후군 위험요인에 대해 Figueiredo 등(2010)의 연구에 의 하면 폐경후에 낮은 고밀도 콜레스테롤과 고혈압은 발생빈도가 높 은 위험요인으로 보고하였으며, 국내 여성을 대상으로 한 연구에서 도 낮은 고밀도 콜레스테롤과 고혈압이 가장 높은 빈도의 위험요인 으로 보고하였다(Lee 등, 2012).

본 연구에서 폐경 전후 대사증후군 위험요인의 차이를 비교한 결과 폐경후 여성에서는 고혈압, 폐경전 여성은 낮은 고밀도 콜레 스테롤혈증이 가장 높은 빈도를 보였다. 특히 폐경전 여성의 $28.1 \%$ 에서 고밀도 콜레스테롤혈증을 보여 여성에 있어서 폐경전부터 고 지혈증 관리가 필요한 것으로 나타났다.

폐경후 여성에서 대사증후군의 유무에 따른 위험요인의 차이를 비교한 본 연구결과 대사증후군 진단군의 경우 체질량지수, 허리둘 레, 혈압, 중성지방, 공복혈당, 당화혈색소, 페리틴, 철결합능은 높 게 나타났으며, 고밀도 콜레스테롤과 혈청 철은 낮게 나타났다. 특 히 복부비만은 폐경 전후 모두에서 대사증후군 진단군에서 복부비 만 기준인 $80 \mathrm{~cm}$ 를 초과하는 $87 \mathrm{~cm}$ 로 나타났다.

우리나라 여성의 $61.4 \%$ 는 복부비만으로 보고되고 있으며, 연령 이 증가함에 따라 폐경으로 인한 호르몬 변화로 엉덩이와 허벅지에 주로 분포하던 지방세포가 폐경 이후 복부로 집중되는 내장형 비만 으로 변화한다(Yeo, 2002; Kim 등, 2005). 그러나 이와 같은 폐경 후 여성의 복부비만은 호르몬 변화와 더불어 생활환경 변화에 따른 운동부족과 식습관에 의한 것으로 생각된다. 게다가 복부비만은 심 혈관계 질환을 포함한 만성질환의 발병률을 증가시키므로, 여성에 서 신체활동을 통한 복부비만 관리가 요구된다(Després 등, 2008).
혈청 페리틴은 체내에 저장된 철의 양을 반영하는 지표로써 (Cho 등, 2011), 혈중 페리틴의 증가는 복부비만 뿐만 아니라, 고혈 압, 고지혈증, 당뇨병을 포함하는 대사증후군 및 심혈관 질환과 밀 접한 관련이 있는 것으로 알려져 있다(Gillum, 2001; Piperno 등, 2002; Williams 등, 2002; Sun 등, 2008).

본 연구결과 폐경전후 여성 모두에서 혈청 페리틴 수치는 대사 증후군 진단군에서 높은 것을 알 수 있었다. 폐경후 여성의 페리틴 수치는 폐경전 여성에 비해 2 3배 증가하며, 혈중 페리틴의 증가 는 산화 스트레스에 의한 조직손상을 유발하여 대사증후군 및 심혈 관 질환의 위험률을 증가시킨다(Lee 등, 2010). 그러나 더 정확한 규명을 위해서는 대사증후군 위험요인을 교정한 후 혈청 페리틴이 감소하는지에 대한 전향적인 추가 연구가 필요할 것으로 생각된다. 또한 본 연구결과 폐경에 영향을 미치는 대사증후군 위험요인은 허 리둘레, 공복혈당, 고밀도 콜레스테롤로 나타나, 폐경이후 비만, 당 뇨 및 고지혈증에 대한 관리가 더욱 요구된다.

본 연구의 제한점으로는 횡단적 자료를 이용한 조사연구로써 인 과관계를 파악하기 어렵다는 점이며, 대상자들의 폐경유무를 난포 자극호르몬 수치를 배제한 설문지 조사결과로 한정하였다는 점이 다.

결과적으로 본 연구를 통해 여성의 폐경전후 대사증후군 유명률 과 위험요인의 차이를 확인하였으며, 폐경후 여성에서 적극적인 비 만과 혈중지질 관리가 필요한 것을 알 수 있었다.

\section{Acknowledgements: None \\ Funding: None \\ Conflict of interest: None}

\section{References}

1. Carr MC. The emergence of the metabolic syndrome with menopause. J Clin Endocrinol Metab. 2003, 88:2404-2411.

2. Cho GJ, Shin JH, Yi KW, Park HT, Kim T, Hur JY et al. Serum ferritin levels are associated with metabolic syndrome in postmenopausal women but not in premenopausal women. Menopause. 2011, 18:1120-1124.

3. Després JP, Lemieux I, Bergeron J, Pibarot P, Mathieu P, Larose $\mathrm{E}$ et al. Abdominal obesity and the metabolic syndrome: contribution to global cardiometabolic risk. Arterioscler Thromb Vasc Biol. 2008, 28:1039-1049.

4. Executive Summary of The Third Report of The National Cholesterol Education Program (NCEP) Expert Panel on Detection, Evaluation, And Treatment of High Blood Cholesterol In Adults (Adult Treatment Panel III). JAMA. 2001, 285:2486-2497.

5. Figueiredo Neto JA, Figuerêdo ED, Barbosa JB, Barbosa Fde F, 
Costa GR, Nina VJ, et al. Metabolic syndrome and menopause: cross-sectional study in gynecology clinic. Arq Bras Cardiol. 2010, 95:339-345.

6. Ford ES, Giles WH, Dietz WH. Prevalence of the metabolic syndrome among US adults: findings from the third National Health and Nutrition Examination Survey. JAMA. 2002, 287: 356-359.

7. Gillum RF. Association of serum ferritin and indices of body fat distribution and obesity in Mexican American men-the Third National Health and Nutrition Examination Survey. Int J Obes Relat Metab Disord. 2001, 25:639-645.

8. International Diabetes Federation. The IDF consensus worldwide definition of the metabolic syndrome. IDF communications. 2006.

9. Kim HM, Park J, Ryu SY, Kim J. The effect of menopause on the metabolic syndrome among Korean women: the Korean National Health and Nutrition Examination Survey, 2001. Diabetes Care. 2007, 30:701-706.

10. Kim MH, Kim MK, Choi BY, Shin YJ. Prevalence of the metabolic syndrome and its association with cardiovascular diseases in Korea. J Korean Med Sci. 2004, 19: 195-201.

11. Kim YH, Ou SW, Kim YS, Chun JH, Yang YJ, Yoon YS, et al. The factors affecting the fat distribution in the abdomen of obese women. J Korean Soc Study Obes. 2005, 14:39-46.

12. Korea Centers for Disease Control and Prevention. The 5th Korea National Health and Nutrition Examination Survey (KNHANES-V, 2012). https://knhanes.cdc.go.kr/knhanes/index.do, last visited on 2014 May 30.

13. Lee HJ, Kwon HS, Park YM, Chun HN, Choi YH, Ko SH, et al. Waist circumference as a risk factor for metabolic syndrome in Korean adult; evaluation from 5 different criteria of metabolic syndrome. J Korean Diabetes Assoc. 2005, 29:48-56.

14. Lee HS, Jun YE, Lim KJ, Yang HI, Lee KE, Kim HY, et al. Effect of serum ferritin concentration on health in postmenopausal women. Korean J Obstet Gynecol. 2010, 96:227.

15. Lee KS, Kim SC, Jung JE, Joo JK, Son JB. Differences of prevalence and components of metabolic syndrome according to menopausal status. J Korean Soc Menopause. 2012, 18:155-162.
16. Levesque J, Lamarche B. The metabolic syndrome: definitions, prevalence and management. I Nutrigenet Nutrigenomics. 2008, 1:100-108.

17. Lovejoy JC. The menopause and obesity. Prim Care. 2003, 30:317-325.

18. Moon HK, Kim YD, Yang DG, Kim SG, Cha KS, Kim MH, et al. Age and Gender Distribution of Patients with Acute Myocardial Infarction Admitted to University Hospitals during the Period of 1990-1999. Korean Circ J. 2003, 33:92-96.

19. Najarian RM, Sullivan LM, Kannel WB, Wilson PW, D'Agostino RB, Wolf PA. Metabolic syndrome compared with type 2 diabetes mellitus as a risk factor for stroke: the Framingham Offspring Study. Arch Intern Med. 2006, 166:106-111.

20. Pandey S, Srinivas M, Agashe S, Joshi J, Galvankar P, Prakasam CP, et al. Menopause and metabolic syndrome: A study of 498 urban women from western India. J Midlife Health. 2010, 1:63-69.

21. Park YW, Zhu S, Palaniappan L, Heshka S, Carnethon MR, Heymsfield SB. The metabolic syndrome: prevalence and associated risk factor findings in the US population from the Third National Health and Nutrition Examination Survey, 1988-1994. Arch Intern Med. 2003, 163:427-436.

22. Piperno A, Trombini P, Gelosa M, Mauri V, Pecci V, Vergani A, et al. Increased serum ferritin is common in men with essential hypertension. J Hypertens. 2002, 20:1513-1518.

23. Sun L, Franco OH, Hu FB, Cai L, Yu Z, Li H, et al. Ferritin concentrations, metabolic syndrome, and type 2 diabetes in middle-aged and elderly chinese. J Clin Endocrinol Metab. 2008, 93:4690-4696.

24. von Muhlen D, Safii S, Jassal SK, Svartberg J, Barrett-Connor E. Associations between the metabolic syndrome and bone health in older men and women: the Rancho Bernardo Study. Osteoporos Int. 2007, 18:1337-1344.

25. Williams MJ, Poulton R, Williams S. Relationship of serum ferritin with cardiovascular risk factors and inflammation in young men and women. Atherosclerosis. 2002, 165:179-184.

26. Yeo E. Menopause, aging and obesity. J Korean Soc Study Obes. 2002, 11:289-298. 